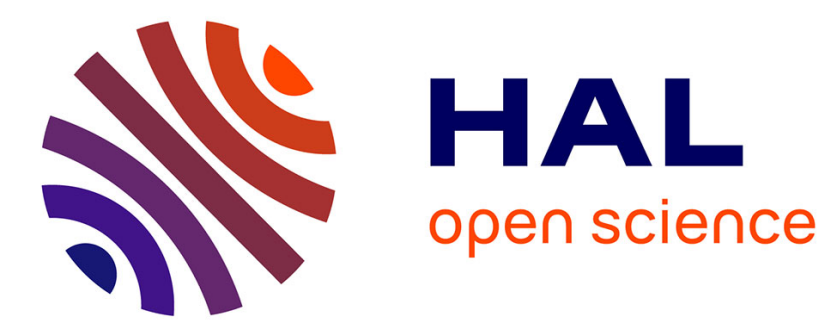

\title{
The impact of inter-municipal cooperation on local public spending
}

Quentin Frère, Matthieu Leprince, Sonia Paty

\section{To cite this version:}

Quentin Frère, Matthieu Leprince, Sonia Paty. The impact of inter-municipal cooperation on local public spending. 2012. halshs-00730555

\section{HAL Id: halshs-00730555 \\ https://shs.hal.science/halshs-00730555}

Preprint submitted on 11 Sep 2012

HAL is a multi-disciplinary open access archive for the deposit and dissemination of scientific research documents, whether they are published or not. The documents may come from teaching and research institutions in France or abroad, or from public or private research centers.
L'archive ouverte pluridisciplinaire HAL, est destinée au dépôt et à la diffusion de documents scientifiques de niveau recherche, publiés ou non, émanant des établissements d'enseignement et de recherche français ou étrangers, des laboratoires publics ou privés. 
The impact of inter-municipal cooperation on local public spending

Quentin Frère, Matthieu Leprince, Sonia Paty 


\section{GATE Groupe d'Analyse et de Théorie Économique Lyon-St Étienne}

93, chemin des Mouilles 69130 Ecully - France

Tel. +33(0)4 72866060

Fax $+33(0) 472866090$

6, rue Basse des Rives 42023 Saint-Etienne cedex 02 - France

Tel. +33 (0)4 77421960

Fax. +33 (0)4 77421950

Messagerie électronique / Email : gate@gate.cnrs.fr

Téléchargement / Download : http://www.gate.cnrs.fr - Publications / Working Papers 


\title{
The impact of inter-municipal cooperation on local public spending
}

\author{
Quentin Frère \\ INRA, UMR1041 CESAER - Université de Bourgogne \\ 26 bd du Dr Petitjean \\ Dijon, France \\ quentin.frere@dijon.inra.fr \\ Matthieu Leprince (corresponding author) \\ CREM (CNRS et université de Rennes 1) \\ 7 Place Hoche \\ Rennes, France \\ matthieu.leprince@univ-rennes1.fr
}

Sonia Paty

Université de Lyon 2, Université de Lyon, Lyon, F-69007 ; CNRS, GATE Lyon Saint Etienne, Ecully, F-69130, France

paty@gate.cnrs.fr

\begin{abstract}
:
The purpose of this paper is to assess the effects of inter-municipal fiscal cooperation on municipal public spending, based on the French experience. We estimate a model of municipal spending choice using panel data and spatial econometrics for municipalities over the period 19942003. We provide two main results. First, inter-municipal cooperation has no significant impact on the level of municipal public spending, which suggests that cooperation does not achieve its goal of reducing municipal spending by the sharing of local responsibilities. Second, there are no spending interactions between municipalities belonging to the same inter-municipal community. This is in line with the goal assigned to cooperation in terms of internalization of spatial externalities. However, our results show that benefit spillovers remain highly significant outside inter-municipal communities, suggesting that inter-municipal communities remain too small.
\end{abstract}

Keywords: public spending, local governments, inter-municipal cooperation, panel data. JEL codes: C2, H2, H4, H7. 


\section{Introduction}

Since the 1950s, local governments in many European countries (Austria, Sweden, Finland, Germany, Switzerland, France...) have been cooperating and nowadays, the encouragement of cooperation among local authorities in the provision of local public goods remains on the political agendas of many central and local governments (Hulst and van Montfort, 2007). There are several reasons for this widespread and persistent phenomenon (see details in e.g. Blume and Blume, 2007). First, larger spatial units are expected to be more competitive in a globalized world. Second, as governments try to reduce the cost of providing public goods, the achievement of economies of scale in the provision of local public services is a strong incentive to cooperate. Third, fiscal cooperation allows jurisdictions to internalize spending spillovers: the benefits of public expenditure (infrastructure, road building, cultural facilities...) often spread across the boundaries of the supplying jurisdiction and affect the welfare of the citizens in neighboring localities.

Despite frequent claims that cooperation among local governments is a potential solution to inefficiencies, there are few studies on that topic. This paper tries to bridge the gap using the French experience and provides estimates of the different effects of fiscal cooperation on municipal spending decisions between 1994 and 2003. The French case offers a favorable setting for research on inter-municipal cooperation. In 1971, there was an unsuccessful attempt by central government to force the country's municipalities to merge. Since then, and contrary to Belgium, England and Germany, for example, the French central government suggests that municipalities should voluntary cooperate within larger jurisdictions known as inter-municipal communities or 'Etablissements Publics de Coopération Intercommunale' (EPCI). Thus, municipalities that want to jointly finance and provide some public services on a collective basis can create or join a community. These supramunicipal structures co-exist with the municipal structures but have different responsibilities, depending on member municipalities' choices regarding the competences to transfer to their community. And French inter-municipal communities benefit from a high level of fiscal autonomy to set tax rates and to choose the scope of inter-municipal public services. 
Our central concern is to disentangle the different possible effects of cooperation on spending behaviors by municipalities. Our first aim is to investigate how fiscal cooperation influences the level of municipal public spending. To our knowledge, very few papers analyze the impact of inter-municipal cooperation on municipal decisions although its effect is a priori not known. An initial benchmark could be the related papers by Turnbull and Djoundourian (1993) and Aronsson et al. (2000), which focus on the effect of the overlapping structure of local governments on public spending. They estimate the impact of regional spending on the local spending choice and find that public goods provided by the higher and the lower levels of overlapping governments tend to be complements. Adapting their framework, and focusing on the inter-municipal level as the higher local government level, Leprince and Guengant (2002) and Guengant and Leprince (2006), using cross-sections of municipal and inter-municipal spending data, show that inter-municipal spending has a significant and negative impact on municipal spending. Thus, community and municipality public goods tend to be substitutes. However, these last papers use only cross-sectional data and either ignore or do not control adequately for spatial interactions between neighboring municipalities, although this should be a central concern of the municipal spending model. Indeed, fiscal cooperation, among other goals, intends to internalize spending spillovers between municipalities of the same community. Therefore, in addition to the study of the possible effect of cooperation on the level of municipal spending, our second aim is to develop and estimate models of municipal spending that are fully specified: they should include spatial interactions between neighboring municipalities, but they also should adequately allow fiscal cooperation to impact the nature and the extent of these possible spatial interactions.

While many empirical papers have investigated the extent of tax interactions between local governments, studies on the existence and the nature of local governments' interactions in terms of spending are scarce. Sollé-Ollé (2006) uses a cross-section of 2610 Spanish municipalities in 28 metropolitan areas and finds negative spatial dependency between neighboring municipalities' overall spending decisions. He shows also that this broad result is driven by urban municipalities in 
the suburbs and that the significance of these spending interactions disappears if the focus is on non-urban or city centers' spending decisions. Schaltegger et al. (2009) study a panel data set of 107 Swiss municipalities in the canton of Lucerne and find that in this small metropolitan area, horizontal overall spending interactions are slightly significant and positive. However, these interactions tend to be highly significant and negative for important categories of spending such as education, health, and environment. Revelli (2003) uses cross-sectional data on the spending decisions of 238 districts and 34 counties. The dataset allows him to study local governments located in non-metropolitan parts of England which have two-tier systems of local government. His estimated spending model includes both the overlapping structure of local governments and possible horizontal interactions. Empirical evidence shows that public goods provided by overlapping local governments tend to be complements, but that when this effect is controlled for, the extent of horizontal spending interactions at the lower level of local governments is low, but still positive. Using a panel data set of the spending decisions of more than 50,000 inhabitants French municipalities, Foucault et al. (2008) provided strong empirical evidence of positive strategic interactions between the biggest French municipalities in relation to primary and investment spending. However, their empirical model ignores both the possible direct effect of fiscal cooperation on the level of municipal spending, and the indirect effect of cooperation on the extent of horizontal interactions.

Lastly, the study that is the closest to ours is led by Ermini and Santolini (2010). They investigate the impact of inter-jurisdictional agreements in Italy on the extent of spending interactions, focusing on specific categories of expenditures. They find that, for the two spending categories where the partnerships are very active - police and road maintenance - strategic interactions among jurisdictions in voluntary partnerships are lower than among isolated municipalities. This outcome suggests that the benefits of spillovers may be internalized in specific cases.

This survey shows that several institutional contexts and empirical models with spatial 
interactions have been studied. However, it is difficult to make clear inferences about the effects of fiscal cooperation on the level of municipal spending and on the existence and the nature (positive or negative) of horizontal spending interactions between neighboring municipalities. We try to fill these gaps using a general model of municipal spending choice which combines spatial interactions terms and fiscal cooperation terms. Our panel data set of French urban municipalities for 1994-2003 and the use of spatial econometric techniques allow us to provide two mains results. First, intermunicipal cooperation has no significant impact on the level of municipal public spending, which suggests that cooperation does not achieve its goal of reducing municipal spending by the sharing of local responsibilities. Second, there are no spending interactions between municipalities belonging to the same inter-municipal community. This is in line with the goal assigned to cooperation in terms of internalization of spatial externalities.

We believe that this paper will contribute to the ongoing debate on the reorganization of subnational jurisdictions, not just in France but also in all those countries that favor the creation of inter-municipal agreements. Our work promotes the idea that cooperation through the creation of a new level of local government (i.e. the inter-municipal community) may reduce spending spillovers among cooperating local governments.

The paper is organized as follows. Section 2 presents the local governments in France. Section 3 discusses the empirical design of the estimations and the data. Section 4 presents the estimation results. Section 5 concludes.

\section{The French institutional context}

French municipalities were subjected to huge change at the beginning of the 1980s. The decentralization process introduced in March 1982 and January 1983 greatly modified the budgetary choices of local authorities which became responsible for implementing public policies on urban infrastructures, economic and social aspects, health, supply of transport for school children, first degree education and supply of school equipment, and culture. Prior to the laws on 
decentralization, municipalities were in charge of general affairs (elections, administrative and civil registration, first degree education since the Ferry Law in 1881, local road safety and road maintenance). The transfer of additional responsibilities has resulted in municipalities increasing their tax receipts and benefitting from higher grants from central government.

The current French local institutional context is characterized by three tiers of overlapping local governments. The lowest tier consists of some 36,600 municipalities; the middle tier consists of 96 counties (or "départements"); and at the highest level of local government are 22 regions. Municipalities are responsible for local urban services, building, provision of nurseries and primary schools, and sport facilities, and maintenance of municipal roads and urban public transport. Counties administer social assistance, and maintain the counties' roads and middle schools. Regions are responsible for the provision of vocational training, economic development and building, and high school provision.

Most local revenues come from taxation (54\%) and grants (23\%), the rest coming from user charges and loans. The local business tax (or "Taxe Professionnelle") is the major source of local government tax revenue, accounting for approximately $45 \%$ of the revenues derived from direct local taxes. ${ }^{1}$ The tax base consists mainly of capital goods and is based on the rental values of buildings and of equipment (assumed to be $16 \%$ of the cost of the equipment). The remaining three taxes are collected from households in the form of residential tax ("taxe d'habitation"), property tax (“taxe foncière sur le bâti”) and land tax ("taxe foncière sur le non bâti”).

In 1992, 1999 and 2004, three laws were passed relating to local cooperation in France. ${ }^{2}$ Based on the volunteer principle, neighboring municipalities that want to finance and manage collectively some public services can create, or join, a community or EPCI. In practice, municipalities decide which local public services (with responsibilities like space planning, economic development, transport, environment, etc) will be delegated to the community. The EPCI

\footnotetext{
${ }^{1}$ This tax was abolished in 2010 and replaced by a territorial economic contribution based on property and value added.

${ }^{2}$ The law of $6^{\text {th }}$ February 1992 lays the basis for inter-municipal cooperation and was reinforced and simplified by the law of $12^{\text {th }}$ July 1999 . The law of $13^{\text {th }}$ August 2004 rationalized the inter-municipal map and forced municipalities to detail the way they share responsibilities with their community.
} 
is governed by a board of delegates elected by municipal councils among their members. ${ }^{3}$ Therefore, unlike council members in municipalities, "départements" or regions, EPCI officials are not directly elected by the population.

\section{The empirical design}

In this section, we first discuss the empirical spending model used to estimate the impact of fiscal cooperation on municipal spending choices. Second, we describe the econometric method used. Third, we present the data used in our study.

\subsection{The empirical model of municipal spending}

Here, we describe our empirical strategy to disentangle, in a spatial model, the possible different effects of inter-municipal cooperation on local spending. Our three step approach is the following. First, we develop the basic spatial model of municipal spending with a single interaction term, as it is already done in the related literature (3.1.1). Second, we introduce in that model a direct possible effect of fiscal cooperation on the level of municipal public spending (3.1.2). Third, we develop an original spatial model with two interaction matrices. This model is able to investigate whether fiscal cooperation has an impact on the extent of spending interactions among neighboring municipalities (3.1.3).

\subsubsection{The basic spatial model of municipal spending}

As a first step, we present a simple municipal model of public spending with spatial interactions among local jurisdictions (see Brueckner, 2003; Revelli, 2005). Each municipality $i$ chooses its spending level $Z_{i}$, which is also affected by the level of spending chosen in the other jurisdictions $Z_{j}$. Thus, the municipality's objective function can be written:

\footnotetext{
${ }^{3}$ Each municipality must have at least one seat, and no single municipality can hold more than half of the intermunicipal council seats. The number of seats held by a municipality is generally proportional to the municipal population.
} 


$$
U\left(Z_{i, t}, Z_{j, t}, X_{i, t}\right)
$$

where $X_{i}$ is a vector of the characteristics of the municipality $i$.

In order to maximize its objective function, the municipality $i$ chooses the spending level that satisfies $\partial U / \partial Z_{i}$. Basically, the solution of this maximization problem is a reaction function such as:

$$
Z_{i, t}=R\left(Z_{j, t}, X_{i, t}\right)
$$

Thus, the spending decision of the municipality $i$ depends on other municipalities' spending choices and on the municipality $i$ 's characteristics. Besides, the sign of the reaction function's slope can be positive or negative, depending on the properties of municipal preferences (Brueckner 2003, p.177). Therefore, the specification of such a spending model can be written as:

$$
Z_{i, t}=\alpha+\beta W Z_{j, t}+X_{i, t} \eta+\varepsilon_{i, t}
$$

where $\alpha$ is a constant term, $\varepsilon_{i, t}$ is a random term, $\beta$ and $\eta$ are the unknown parameters to be estimated.

The significance of parameter $\beta$ is expected to reveal whether there are spatial interactions between municipalities when they choose their level of public spending. A negative sign of $\beta$ would indicate the presence of substantive spending spillovers: the inhabitants of neighboring municipalities benefit from the local services provided by the municipality $i$. In comparison, a positive sign of $\beta$ would reveal local competition, due either to tax base mobility (see Wilson, 1999, for a survey on tax competition) or to a yardstick competition mechanism (Salmon, 1987; Besley and Case, 1995). In the first case, municipalities try to attract a part of their neighbors' tax base in order to increase their tax revenues, which lead to a race-to-the-bottom of tax rates. In the second case, incumbents adopt a mimicking behavior in order to maximize their probability of being reelected. But whatever the sources of spatial interactions ${ }^{4}$, this model of municipal spending is not satisfactory in the French local government context because it ignores fiscal cooperation

\footnotetext{
${ }^{4}$ See Redoano (2007) for a methodology to identify the source of such horizontal interactions.
} 
between municipalities.

\subsubsection{The impact of inter-municipal cooperation on the level of municipal spending}

In a second step, we extend this basic spatial framework in order to investigate the impact of local cooperation on municipalities' spending choices. First, we focus on the direct effect of cooperation on the level of municipal spending by including a dummy variable Coop. It captures the cooperation choice of the municipality, such as Coop is equal to 1 if the municipality $i$ is part of an intermunicipal community, and equal to 0 otherwise. Thus, a municipality's policy reaction function can be written as:

$$
Z_{i, t}=R_{i}\left(Z_{j, t}, \operatorname{Coop}_{i, t}, X_{i, t}\right)
$$

where $Z_{i, t}$ is the vector of per capita public expenditure of the municipality $i$ at time $t ; Z_{j, t}$ is the vector of per capita public spending of the neighboring municipalities $j$ at time $t$; Coop $_{i, t}$ is the cooperation variable indicating whether or not the locality belongs to a community, and $X_{i, t}$ is the vector of the socio-economic and budgetary characteristics of municipality $i$ at time $t$. The equation to be estimated then becomes:

$$
Z_{i, t}=\alpha_{i}+\beta W Z_{j, t}+\delta \operatorname{Coop}_{i, t}+X_{i, t} \eta+\varepsilon_{i, t}
$$

where $\delta$ is expected to be negative: a municipality belonging to a community transfers some spending responsibilities that are endorsed by its community, and thus, the municipality's spending level is expected to be lower. This is the transferred charges effect.

However, such impact of communities on their member municipalities may differ according to the magnitude of their expenditures. Therefore, in a second time, we replace the Coop dummy by $Z_{I, t}$, the spending level of the community $I$ at time $t$. We estimate the following model:

$$
Z_{i, t}=\alpha_{i}+\beta W Z_{j, t}+\delta Z_{I, t}+X_{i, t} \eta+\varepsilon_{i, t}
$$

This allows us to test whether inter-municipal and municipal public goods and services are either independent (in the case of a non-significant estimated value of $\delta$ ), substitutes (which would 
imply a negative impact of $Z_{I, t}$ ), or complements (which would imply a positive impact of $Z_{I, t}$ ).

\subsubsection{The impact of cooperation on the extent of spatial interactions between municipalities}

Besides this direct effect of cooperation on the level of municipal spending, we focus on the indirect effect of cooperation on the extent of spatial interactions in municipal spending. To do so, we need to refine our analysis by decomposing the spatial interaction term $W Z_{j, t}$ used in equations (5) and (6). Indeed, the model presented in the previous section rests on the hypothesis that interactions do not differ if neighboring municipalities are members of the same inter-municipal community or not. However, this hypothesis should be studied more deeply: by sharing some responsibilities, municipalities member of the same community precisely intend to internalize spillovers in order to improve the efficiency of the local public spending within the community. To study such effect of inter-municipal cooperation on the nature and on the extent of spatial interactions, we decompose $W Z_{j, t}$ into two terms: $W^{\text {SAME }} Z_{j, t}$ and $W^{\text {OTHER }} Z_{j, t}$. The first term $\left(W^{\text {SAME }} Z_{j, t}\right)$ allows us to estimate the impact of the spending of the neighboring municipalities belonging to the same inter-municipal community as the municipality $i$. At the opposite, the second term $\left(W^{\text {OTHER }} Z_{j, t}\right.$ ) allows us to estimate the impact of the spending of the neighboring municipalities outside the when neighbors $j$ do not belong to the same community as municipality $i$. In other words, we distinguish intracommunity $\left(W^{\text {SAME }} Z_{j, t}\right)$ and extra-community $\left(W^{\text {OTHER }} Z_{j, t}\right)$ spatial spending interactions between municipalities.

Using this detailed identification of spatial interactions, we can specify two spatial interactive terms, so that the model to be estimated is as follows:

$$
Z_{i, t}=\alpha_{i}+\mu W^{S A M E} Z_{j, t}+\sigma W^{\text {OTHER }} Z_{j, t}+\delta Z_{I, t}+X_{i, t} \eta+\varepsilon_{i, t}
$$

As cooperation is expected to internalize spending benefit among local governments, we expect a lower absolute value for the parameter $\mu$ (which measures the extent of intra-community spatial spending interactions) than for the parameter $\sigma$ ( which measures the extent of extra-community 
spatial spending interactions). Similarly to the discussion on $\beta$ in equation (3), a negative sign of $\mu$ (resp. $\sigma$ ) will indicate that there are significant spending spillovers among cooperating (resp. noncooperating) municipalities. At the opposite, a positive sign would indicate that there are spending interactions between neighboring municipalities due either to tax base, or to a yardstick competition mechanism. Whatever the sign of the spatial parameters, cooperation is expected to reduce the extent of spatial interactions in municipal spending.

\subsection{Econometric issues}

The empirical literature on spatial spending model highlights two main econometric issues we have to deal with in our estimating strategy.

First, we need to precise the nature of the spatial interaction phenomenon we analyze in our model. This is all the more important that one of the possible effects of inter-municipal cooperation on which we focus is an effect on the extent of spatial interactions. Following the empirical literature, we choose a geographical definition of neighborhood based on the Euclidean distance between municipalities. ${ }^{5}$ This scheme imposes a smooth distance decay, and weights $w_{i j}$ are given by $1 / d_{i j}$ where $d_{i j}$ is the Euclidian distance between municipalities $i$ and $j$ for $j \neq I$. However, in order to make sure that our estimation results are not specific to one (and only one) definition of neighborhood, we have checked their robustness by testing various weight matrices. We study three matrices:

- $\quad \mathrm{W}^{\mathrm{DIST}<20 \mathrm{~km}}$, where $w_{i j}=1 / d_{i j}$ if $d_{i j}<20 \mathrm{~km}$, and $w_{i j}=0$ otherwise;

- $\quad \mathrm{W}^{\mathrm{DIST}<15 \mathrm{~km}}$, where $w_{i j}=1 / d_{i j}$ if $d_{i j}<15 \mathrm{~km}$, and $w_{i j}=0$ otherwise;

- $\quad \mathrm{W}^{\mathrm{CTG}}$, where $w_{i j}=1$ if $j$ is contiguous to $i$, and $w_{i j}=0$ otherwise;

All theses weight matrices are standardized so that $\sum_{j} w_{i j}=1, \quad \forall i$.

Note that although our study is based on urban municipalities, we do not limit our empirical

\footnotetext{
${ }^{5}$ We checked the robustness of this approach and replicated our estimation strategy using a definition of neighborhood based on contiguity, implying that $w_{i j}=1$ if two municipalities share a common border, and $w_{i j}=0$ otherwise.
} 
approach to spatial interactions between these urban units in order to avoid possible border effects. Indeed, such a restriction would bias the estimation results: it would implicitly assume that urban area are similar to island in the country and that urban municipalities only interact with other neighboring urban municipalities, but not at all with neighboring rural municipalities. Therefore, we allow spatial interactions to take place between urban and rural municipalities and thus, we use an extended definition of neighboring municipalities (see next section for a mapping of these buffer areas). More specifically, the neighboring municipalities decisions on spending (either with the $W$ matrix in (3), (5) or (6) or with the $W^{S A M E}$ and $W^{\text {OTHER }}$ matrices in (7)) are computed for urban municipalities and for all municipalities (even rural) considered to be neighbors, that is, municipalities located within a $20 \mathrm{~km}$ distance, or within a $15 \mathrm{~km}$ distance, or contiguous.

However, our second approach, where we distinguish intra-community and extra-community spatial spending interactions with $W^{S A M E}$ and $W^{\text {OTHER }}$, raises a second border effect problem. In order to illustrate this point, we have depicted the case of two member municipalities of the same community: the "Communauté d'agglomération du Grand Dijon" (see Map 1). Those two municipalities have four contiguous neighbors, but Talant is located within the perimeter of the community, whereas Perrigny is located at the border. Thus, Talant's four neighbors belong to the same community (municipalities in dark grey on Map 1.1) but none of them is outside the community. In comparison, Perrigny has one neighbor that belongs to the same community (municipality in dark grey on Map 1.2) and three neighbors outside the community (municipalities in light grey on Map 1.2), As a consequence, Talant's $W^{S A M E}$ matrix is empty when based on the contiguity neighborhood definition. This case is more frequent the more restrictive is the neighborhood definition. Indeed, if we compare it to the case where we use the $20 \mathrm{~km}$ neighborhood definition (see Map 1.3 and 1.4 ), $W^{S A M E}$ and $W^{\text {OTHER }}$ are not empty for both municipalities. This point led us to prefer the distance based neighborhood definition rather than the contiguity based neighborhood definition in the two regimes approach. 


\section{[insert Map 1]}

Our second econometric issue rests on the endogeneity of our spatially lagged variable. Indeed, if localities do react to each others' spending choices, then neighbors' spending decisions are endogenous and correlated with the error term $(\varepsilon)$. As a consequence, ordinary least squares (OLS) yields a biased parameter estimate (Anselin, 1988). Basically, there are two possible approaches that provide consistent estimates of the spatial parameters in our equations of municipal spending. The first is based on an instrumental variables (IV), two-stage least squares (2SLS) method. It consists of finding variables that are correlated with neighbors' fiscal spending choices but uncorrelated with the error term. The IV approach suggests the use of the weighted average of neighbors' exogenous or control variables (WX) as instruments (Kelejian and Robinson, 1993; Kelejian and Prucha, 1998). The second method is based on maximum likelihood (ML). Under this method, a non-linear reduced form of the estimated equations is computed by inverting the system. A non-linear optimization routine is used to estimate the spatial coefficient.

In this paper, we compute heteroskedasticity-robust IV/GMM estimators for three main reasons. First, as argued before, our main variable of interest (the $\operatorname{Coop}_{i, t}$ dummy or inter-municipal spending $\left.Z_{I, t}\right)$ is suspected of endogeneity. Yet, Fingleton and Le Gallo $(2007,2008)$ have shown that IV/GMM estimators are useful in those cases, where spatial dependence models contain one or more endogenous explanatory variables other than the spatially lagged dependent variable (see also Elhorst, 2010, p.15). Second, we have chosen a large definition of neighborhood and defined buffer zones in order to avoid border effects (see next section for a mapping of these buffer areas). As a consequence, neighbors can belong to rural areas that are not part of our initial sample of urban municipalities and in that case, the usual ML routines cannot be used. Third, as local public spending may be persistent over time, serial correlation can appear. To deal with this issue, we could introduce the time lagged municipal spending in our explanatory variables and would obtain a dynamic spatial panel a la Arellano and Bond (1991) (e.g. Veiga and Veiga, 2007; Foucault et al., 
2008). However, as it introduces correlation with the municipal fixed effect, this time-lagged dependent variable would have to be instrumented. As we did not find satisfying instruments, we have defined individual clusters in order to get estimation results that are robust to arbitrary intragroup correlation, i.e. to serial correlation in our case (e.g. Arellano, 1987). Finally, if neighbors' localities are subject to correlated shocks, we may find a correlation between jurisdictions' spending choices. The omission of explanatory variables that are spatially dependent may generate spatial dependence in the error term, which is given by the following equation:

$$
\varepsilon_{i, t}=W \varepsilon_{i, t}+u_{i, t}
$$

If we ignore spatial error dependence, the estimation of our equations could provide false evidence of strategic interaction. In this paper, we have run the usual non-robust and robust Lagrange multipliers tests, which confirm the relevancy of a spatial lag model. ${ }^{6}$

Besides, we control both for individual fixed effect by using the Within difference (each variable is expressed in difference to the individual mean), and for year fixed effects by a set of nine year dummies.

\subsection{Data}

Our study focuses on urban municipalities ${ }^{7}$ located in the French metropolitan areas (pôle urbain according to the $\mathrm{INSEE}^{8}$ ). We selected only those urban municipalities that existed from the beginning to the end of our period of study (1994-2003), which yielded a sample of 2,895 municipalities over 9 years and a total of 26,055 observations. Expenditures data come from the Direction Générale des Collectivités Locales (DGCL, Ministère de l'Intérieur) for municipal governments $^{9}$ and the remaining control variables from French census data. Descriptive statistics

\footnotetext{
${ }^{6}$ They are not presented here for the sake of place but can be shown upon request.

${ }^{7}$ This restriction is due to two reasons. First, urban and rural municipalities may present different behavior in terms of public policies, and different reactions to cooperation. To cope with that heterogeneity, we focus on urban municipalities' public spending decisions. Second, there are technical difficulties related to computing spatial estimations over the whole country since French municipal governments are about 36,600 municipalities.

${ }^{8}$ Urban unit with more than 5,000 jobs.

${ }^{9}$ Expenditures data for inter-municipal communities are not publicly available. They used a proxy according to a method already used by Leprince and Guengant (2002): we added for each community the two main sources of
} 
are given in Table 1.

Map 2 shows the spatial distribution of the French urban municipalities that we study in this paper. Recall that neighbors' spending decisions are computed over our 2,895 urban municipalities and also over all municipalities considered as a neighbor, (i.e. located within $20 \mathrm{~km}$ ) to avoid possible border effects across urban and rural municipalities.

[insert Map 2]

In line with the literature, we include four socio-demographic controls and two budgetary variables that may influence local demand for municipal public goods and services:

- Population density (Density $y_{i, t}$ ) is expected to take a positive sign since a big city may supply a high level of local public goods to citizens living within their borders and also to the citizens of the neighboring localities;

- Proportions of the population aged below $14\left(\right.$ Pct_Young $\left._{i, t}\right)$ and above 60 years $\left(\right.$ Pct_Old $\left._{i, t}\right)$ which are presumed to take account of municipal demographic heterogeneity influencing the demand for local spending. We would expect these control variables to be associated with a positive sign because of the particularly high demand of these two populations for local public services;

- Since we expect demand for local public goods and services to be higher among richer citizens (i.e. local public goods are considered to be normal or superior goods, depending on the value of citizens' income-elasticity), after-tax yearly mean income (Mean_Income $e_{i, t}$ ) should have a positive impact on the level of municipal expenditures;

- A municipal tax capacity per capita variable (Tax_Capacity $\left.{ }_{i, t}\right)$ is included as an explanatory variable to control for the fact that wealthier municipalities can afford higher levels of public

fiscal revenues (accounting for more than $70 \%$ of total revenues): tax revenues and central government's block grants. Re-assignments of inter-municipal tax revenues to municipal governments were controlled for when necessary due avoid double counting. 
spending. Tax capacity is defined and computed by the central government as the tax revenues a local government might receive if its local tax bases would be taxed at a tax rate equal to the mean tax rates calculated all over the country for the same level of local government.

- A municipal grant variable $\left(\right.$ Grant $\left._{i, t}\right)$ that refers to the amount per capita of Dotation Globale de Fonctionnement (DGF), the main block grant that each municipality receives from the central government according to a national formula that mainly rests on municipal population.

\section{Results}

We present our estimation results in the following way. In a first step (4.1), we provide results when models (3), (5) and (6) are estimated. Model (3) is the basic spatial model of municipal spending and ignores fiscal cooperation. Models (5) and (6) introduce the potential effect of cooperation on the level of municipal spending. In a second step (4.2), we refine our estimation strategy and investigate whether spatial interactions between municipalities are different when we introduce two types of matrix in the model to control for the fact that some municipal neighbors belong to the same community whereas others do not. This gives us results of the estimation of model (7).

\subsection{Baseline Results}

Table 2 presents the estimation results of the model (3) in column (2.1) and then results for models (5) and (6) in the following columns. Columns (2.2) and (2.3) include the Coop dummy as an explanatory variable to capture the effect of fiscal cooperation on the level of municipal spending. Columns (2.4) and (2.5) provide the estimation results including the level of inter-municipal spending in the model. In all columns, spatial lag variables with a unique distance matrix $W$ are instrumented (see the instruments used in the bottom of Table 2) whereas variables of interest (i.e. Coop and $Z_{I, t}$ ) are instrumented only in columns (2.3) and (2.5). 
Estimation results of the basic spatial model (3) indicate that there are very significant spatial interactions between municipalities located within a distance lower than $20 \mathrm{~km}$. More specifically, the estimated spatial lag parameter is 0.744 in column 2.1 of Table 2. This result holds with a small variation in the estimated parameter when a direct effect of cooperation on the level of municipal spending is introduced in the model (see the following columns in the same table). This gives evidence of positive spatial interactions in public spending between municipalities. This is consistent with the evidence first provided by Jayet et al. (2002) and Charlot and Paty (2010) when different cross-sections of municipal tax rates were studied. However, this is the first evidence given with panel data and when spatial interactions in municipal spending are studied for municipalities of different sizes included in the same "bassin de vie". Foucault, Madies and Paty (2008) also found positive spatial interactions but focused on a panel of municipalities of more than 50,000 inhabitants and ignored the possible effect of cooperation on municipal spending.

Finally, in our spatial model, apart from significant time fixed effects, only two explanatory variables appear to be significant: higher income per capita leads to lower municipal spending, contrary to what is expected, but with a low level of significance, whereas a higher tax capacity per capita leads to higher municipal spending, which is in line with results obtained in previous studies on the French case (see Leprince and Guengant (2002) for example). The other potential explanatory variables of the model appear to be never significant whatever the specifications used in Table 2, but also in Table 3.

Result 1. Controlling for the possible effect of cooperation on the level of municipal spending, our baseline estimation results show that spatial interactions in municipal spending are very significant and positive between French municipalities.

Focusing now on the effect of cooperation on the level of municipal spending, we provide results in column (2.3) (resp. 2.5) where the possible endogeneity of Coop (resp. the level $Z$ of inter-municipal spending) is controlled for. We show that the estimated parameters are never 
significantly different from zero: local cooperation does not modify the level of municipal public spending. This outcome suggests that the single fact for an urban municipality to be a member of an inter-municipal community does not lead to significantly different spending behavior, compared to isolated municipalities.

\section{Result 2. Inter-municipal cooperation per se does not have any impact on the level of municipal spending.}

There are several possible reasons for this result of independence between municipal spending and inter-municipal or community spending. First, the community might provide public goods not previously supplied by rather small municipalities, such as a public swimming pool: this is the "Zoo effect" identified by Oates (1988) (see some French evidence by Frère et al. (2011)). In such cases, the scope of municipal public goods is not reduced by inter-municipal cooperation, and both levels of public spending are independent. Second, in some cases, there may be two phenomena that are compensating for each other (see Leprince and Guengant (2002)). On the one hand, local cooperation among municipalities is a more effective means to provide public goods that the local authorities concerned were already providing before the cooperation. In such cases, the Coop dummy would be significant and negative because the scope of municipal provision is reduced by cooperation. On the other hand, municipalities may react to the extended scope of intermunicipal provision of public goods by improving the quality of the supplied goods and services or by extending the scope of their public goods provision to satisfy previously unfulfilled demand. In some communities, this municipal behavior might induce a positive impact if the Coop dummy. These effects with opposite signs might be compensating producing a non-significant result overall.

Finally, let us remark that our Result 2 is obtained in a spatial model of municipal spending. When the spatial lag variable is omitted (see Table Al in the appendix), the effect of fiscal cooperation on municipal spending becomes significant and negative in our panel approach; in line with cross-sectional evidence provided by Leprince and Guengant (2002). However, these 
significant effects of cooperation are obtained from a municipal model which is incorrectly specified, because it ignores significant spatial interactions in spending, leading to biased estimation results. Introducing spatial effects correctly and testing alternative weight matrices in spending models designed to study the effects of inter-municipal cooperation is thus of central concern for the rest of our paper.

\subsection{Municipal spending models where cooperation impacts the extent of spatial interactions}

Our baseline Results 1 and 2 suggest significant spatial interactions in municipal spending and a non-significant effect of fiscal cooperation on the level of municipal spending. However, the spatial nature of our spending model must be more deeply studied so that the robustness of our first results is tested. We investigate that question in two steps.

First, we want to make sure that different weight matrices would lead to the same results. Indeed, our spatial models rest on one weight matrix that defines neighbors as municipalities located in a distance lower than $20 \mathrm{~km}$. To provide robustness checks, we thus estimated our models with two other matrices: one matrix with a $15 \mathrm{~km}$ distance, and one contiguity matrix, where neighbors are the only municipalities that share a common border with the urban municipalities under scrutiny in our study.

Results are given in the Appendix; in Table A2 with the $15 \mathrm{~km}$ distance and in Table A3 with the continuity matrix. They provide two new insights. First, whatever the matrices used, Result 2 remains valid: the impact of cooperation on the level of municipal expenditures is never significant. The estimation of the direct impact of cooperation on municipal spending is thus not dependent on the way spatial interactions are modeled. However, concerning Result 1, these new tables suggest that the definition of the spatial weights matters. First, the $15 \mathrm{~km}$ distance matrix leads to spatial interactions that remain significant but with a somewhat lower absolute value of the spatial lag parameter. Second, the contiguity matrix leads to non-significant spatial interactions, the rests of the model being stable with the Tax capacity variable remaining the main significant variable. These 
results obtained when the distance between urban municipalities and their neighbors declines contradict our a priori according to which the lower the distance between urban units, the higher spatial interactions.

These results suggest the need to carefully examine the nature of spatial interactions in our model. Our hypothesis is that spatial models used in the beginning of this paper neglect a second effect of cooperation on municipal behavior. More specifically, the models (3) to (6) rest on the hypothesis that interactions do not differ if neighboring municipalities are members of the same inter-municipal community. Our intend here is to analyze more deeply this hypothesis since members of the same community share spending responsibilities and intend to internalize benefit spillovers so that local public spending in the community is more efficient. Cooperation thus intends not only to reduce the level of municipal spending, but also to internalize spatial externalities. In other terms, cooperation should play a role in the nature and in the extent of spatial interactions between neighboring municipalities.

To study the possible effect of cooperation on spatial interactions, we decompose $W Z_{j, t}$ into two terms, $W^{\text {SAME }} Z_{j, t}$ and $W^{\text {OTHER }} Z_{j, t}$. As explained in section 3 , the estimation of the $W^{\text {SAME }} Z_{j, t}$ parameter allows us to estimate the impact on urban municipalities $i$ of neighboring municipal spending only if the neighbors $j$ are included in the same inter-municipal community as municipality $i$ : thus, these spatial interactions come from intra-community interactions between municipalities belonging to the same community. The second term $W^{\text {OTHER }} Z_{j, t}$ allows us to estimate the impact of neighboring municipalities when neighbors $j$ do belong to the same community as municipality $i$. This is the model (7) presented in section 3 .

Results are displayed in Table 3. While the rest of the model remains stable, with a significant impact of the tax capacity variable, and a non-significant impact of cooperation on the level of municipal spending, the distinction between the two types of spatial interactions strongly modifies the estimation results in a way that is more in line with expectations. When the possible 
endogeneity of the variables Coop, (or Zit) and $W^{\text {SAME }} Z_{j, t}$ and $W^{\text {OTHER }} Z_{j, t}$ is accounted for, in columns (3.3) and (3.5), results greatly support our hypothesis that cooperation modifies the nature of spatial interactions between municipalities in their spending behaviors. Indeed, the estimated coefficient of $W^{S A M E} Z_{j, t}$ is not significant in these columns.

\section{Result 3. There are no spending interactions between municipalities belonging to the same inter-municipal community. Inter-municipal cooperation seems to internalize spending spillovers among cooperating local governments.}

The absence of spending interactions between neighbors in the same community may be one of the main consequences of the decrease in responsibilities when municipalities belong to a community. This is the expected result of internalization of spatial externalities, either in terms of benefit spillovers or in terms of incentives to copy cat neighbors (in tax competition or in yardstick competition models). Therefore, our results suggest that cooperation partially achieves its goals: while it fails to significantly reduce the level of municipal spending (see Result 2), it might be effective in reducing spatial externalities between municipalities of the same community (Result 3)

On the other hand, the estimated parameter of $W^{\text {OTHER }} Z_{j, t}$ is significant and negative. This suggests the existence of significant spending spillovers among neighboring municipalities that do not belong to the same community. Since the coefficient is negative, spatial interactions among local governments cannot be induced by yardstick competition or spending competition over a mobile tax base. Similar to results obtained by other studies (see, e.g. Solé-Ollé (2006) or Schaltegger et al. (2009)) when studying local government behaviors in spatial models, this result confirms that there are strong spending interactions among neighboring municipalities outside intermunicipal communities.

Result 4. Benefit spillovers between municipalities that do not belong to the same community remain significant, suggesting that inter-municipal communities remain too small. 
This result is in line with a well known special report by the Cour des Comptes (2005), according to which the number of municipalities being member of the same community, especially in urban areas, is too low so that inter-municipal communities are not able to internalize the whole extent of benefit spillovers between municipalities. This is why a recent law passed in 2010 recommends to merge communities, and even forces the smaller ones of less than 5,000 inhabitants to do it.

\author{
[insert Table 3]
}

\title{
5. Conclusion
}

Inter-municipal cooperation is a widespread phenomenon occurring in most European countries but its different effects on municipal choices are not a priori known since it might combine reduced costs due to economies of scale, internalization of spending spillovers, and reduced tax competition, among other expected effects.

The main aim of this paper was to test the impact of inter-municipal cooperation on municipal spending behavior. We estimated a model of municipal spending choice using panel data for the period 1994-2003. We found that inter-municipal cooperation does not have per se any impact on the level of municipal spending, contrary to what was expected from the sharing of local responsibilities between municipalities belonging to the same community. We also found that intermunicipal cooperation internalizes spending spillovers among municipalities in the same community. However, benefit spillovers between municipalities that do not belong to the same community remain significant, suggesting that inter-municipal communities remain too small.

We believe that this paper will contribute to the ongoing debate on the reorganization of subnational jurisdictions since our work promotes the idea that cooperation through the creation of a new level of local government (i.e. the inter-municipal community) may reduce spending spillovers 
among cooperating local governments.

Future work could extend the research described here, in various ways. For example, we could investigate whether the results change if we consider different categories of public expenditures. 


\section{References}

Anselin L (1988) Spatial econometrics: Methods and models. Kluwer Academic Publishers, Dordrecht

Arellano M (1987) Computing robust standard errors for within-group estimators. Oxford Bulletin of Economics and Statistics 49: 431-434

Arellano M and Bond S (1991) Some tests of specification for panel data: Monte Carlo evidence and an application to employment equations. The Review of Economic Studies 58: 277 - 297

Aronsson T, Lundberg J, Wikstrom M (2000) The impact of regional public expenditure on the local decision to spend. Regional Science and Urban Economics 30: 185-202

Besley TJ, Case A (1995) Incumbent behavior: Vote-seeking, tax-setting, and yardstick competition. The American Economic Review 85: 25-45

Blume L, Blume T (2007) The economic effects of local authority mergers: empirical evidence for German city regions. Annals of Regional Science 41: 689-713

Brueckner JK (2003) Strategic interaction among governments: An overview of empirical studies. International Regional Science Review 26: 175-188

Cassette A, Paty S (2006) La concurrence fiscale entre communes est-elle plus intense en milieu urbain qu'en milieu rural ? Cahiers d'Economie et Sociologie Rurales 78: 5-30

Charlot S, Paty S, Piguet V (2009) Intercommunalité et fiscalité directe locale. Economie et Statistique 415: 121-140

Charlot S, Paty S, Piguet V (2010) The effects of fiscal cooperation on local taxation: The French case. CESAER-INRA Working Paper No. 2010-1

Cour des comptes (2005), L'intercommunalité en France; La documentation française, 370 pages.

Devereux MP, Lockwood B, Redoano M (2007) Horizontal and vertical indirect tax competition: Theory and some evidence from the USA. Journal of Public Economics 91: 451-479

Elhorst JP (2010) Applied spatial econometrics: Raising the bar. Spatial Economic Analysis 5: 9-28

Ermini B, Santolini R (2010) Local expenditure in Italian municipalities. Do local council partnerships make a difference? Local Government Studies 36: 655-677

Fingleton B, Le Gallo J (2007) Finite sample properties of estimators of spatial modles with autoregressive, or moving average disturbances and system feedback, Annales d'économie et de statistiques 87-88: 39-62

Fingleton B, Le Gallo J (2007) Estimating spatial models with endogenous variables, a spatial lag and spatially dependent disturbances: finite sample properties. Papers in Regional Science 87: 319-339

Frère Q, Hammadou H, Paty S (2011) Range of local public services and population size: Is there a 
"zoo effect" in French jurisdictions? Louvain Economic Review 77: 87-104

Foucault M, Madies T, Paty S (2008) Public spending interactions and local politics. Public Choice 135: $57-80$

Guengant A, Leprince M (2006) Évaluation des effets des régimes de coopération intercommunale sur les dépenses publiques locales. Économie et prévisions 175: 79-99

Hulst R, van Montfort A (eds) (2007) Inter-Municipal Cooperation in Europe. Amsterdam: Springer.

Kelejian HH, Robinson DP (1993) A suggested method of estimation for spatial interdependent models with autocorrelated errors, and an application to a county expenditure country police expenditure. Papers in Regional Science 72: 297-312

Kelejian HH, Prucha IR (1998) A generalized spatial two-stage least squares procedure for estimating a spatial autoregressive model with autoregressive disturbances. Journal of Real Estate Finance and Economics 17: 99-121

Leprince M and Guengant A (2002) Interactions fiscales verticales et réaction des communes à la coopération intercommunale. Revue Economique 53: 525-535

Oates WE (1988) On the measurement of congestion in the provision of local public goods. Journal of Urban Economics 24: 85-94

Redoano M (2007). Fiscal interactions among European countries. Does the EU matter? CESifo working paper $n^{\circ} 1952$

Revelli F (2003) Reaction or interaction? Spatial process identification in multi-tiered government structures. Journal of Urban Economics 53: 29-53

Revelli F (2005) On spatial public finance empirics. International Tax and Public Finance 12: 475492.

Salmon P (1987) Decentralization as an incentive scheme. Oxford Review of Economic Policy 3: $24-43$

Schaltegger CA, Torgler B, Zemp S (2009) Central city exploitation by urban sprawl? Evidence from Swiss local communities. QUT School of Economics and Finance Working Paper No. 246

Solé-Ollé A (2006) Expenditure spillovers and fiscal interactions: Empirical evidence from local governments in Spain. Journal of Urban Economics 59: 32-53.

Turnbull GK, Djoundourian S (1993) Overlapping jurisdictions: Substitutes or complements? Public Choice 75: 231-245

Veiga L, Veiga F (2007) Political business cycles at the municipal level. Public Choice, 131: 45-64

Wilson JD (1999) Theories of tax competition. National Tax Journal 52: 269-304 


\section{Appendix}

[insert Table Al]

[insert Table A2]

[insert Table A3] 
Table 1. Descriptive statistics, 1994-2003

\begin{tabular}{|c|c|c|c|c|c|}
\hline Description & Symbol & Mean & Std dev. & Min & $\operatorname{Max}$ \\
\hline $\log$ (municipality's expenditure in hundred $€$ p.c.) & $Z_{i, t}$ & 2.34 & 0.48 & -1.57 & 5.45 \\
\hline $\mathrm{W}^{\mathrm{DIST}<20 \mathrm{~km}} * \log$ (municipality's expenditure in hundred $€$ p.c.) & $W Z_{i, t}$ & 2.19 & 0.27 & 1.45 & 4.14 \\
\hline $\mathrm{W}^{\mathrm{SAME}, \mathrm{DIST}<20 \mathrm{~km}} * \log$ (municipality's expenditure in hundred $€$ p.c.) & $W^{S A M E} Z_{i, t}$ & 1.39 & 1.11 & 0.00 & 3.79 \\
\hline $\mathrm{W}^{\mathrm{OTHER}, \mathrm{DIST}<20 \mathrm{~km}} * \log$ (municipality's expenditure in hundred $€$ p.c.) & $W^{\text {OTHER }} Z_{i, t}$ & 2.16 & 0.29 & 0.00 & 4.14 \\
\hline cooperation dummy & $\operatorname{Coop}_{i, t}$ & 0.62 & 0.48 & 0.00 & 1.00 \\
\hline $\log ($ community's expenditure in hundred $€$ p.c. +1$)$ & $Z_{I, t}$ & 0.51 & 0.55 & 0.00 & 3.10 \\
\hline $\log$ (population density) & Density $_{i, t}$ & 6.15 & 1.23 & 2.84 & 10.11 \\
\hline $\log$ (proportion of the population below 14 y.o. +1 ) & Pct_Young $_{i, t}$ & 0.18 & 0.03 & 0.09 & 0.33 \\
\hline $\log$ (proportion of the population above 60 y.o. +1 ) & Pct_Old ${ }_{i, t}$ & 0.17 & 0.04 & 0.02 & 0.38 \\
\hline $\log$ (after-tax yearly mean income) & Mean_income ${ }_{i, t}$ & 5.16 & 0.27 & 4.17 & 6.90 \\
\hline $\log ($ tax capacity in hundred $€$ p.c. +1$)$ & Tax_capacity $_{i, t}$ & 1.80 & 0.49 & 0.00 & 4.40 \\
\hline $\log ($ grants received by the municipality in hundred $€$ p.c. +1$)$ & Grant $_{i, t}$ & 0.95 & 0.28 & 0.00 & 2.26 \\
\hline Number of municipalities & & & & & 2,895 \\
\hline Number of observations & & & & & 28,950 \\
\hline
\end{tabular}

Monetary terms are expressed in constant euros, base 2005.

Map 2. Spatial distribution of the French urban municipalities studied and their neighbors

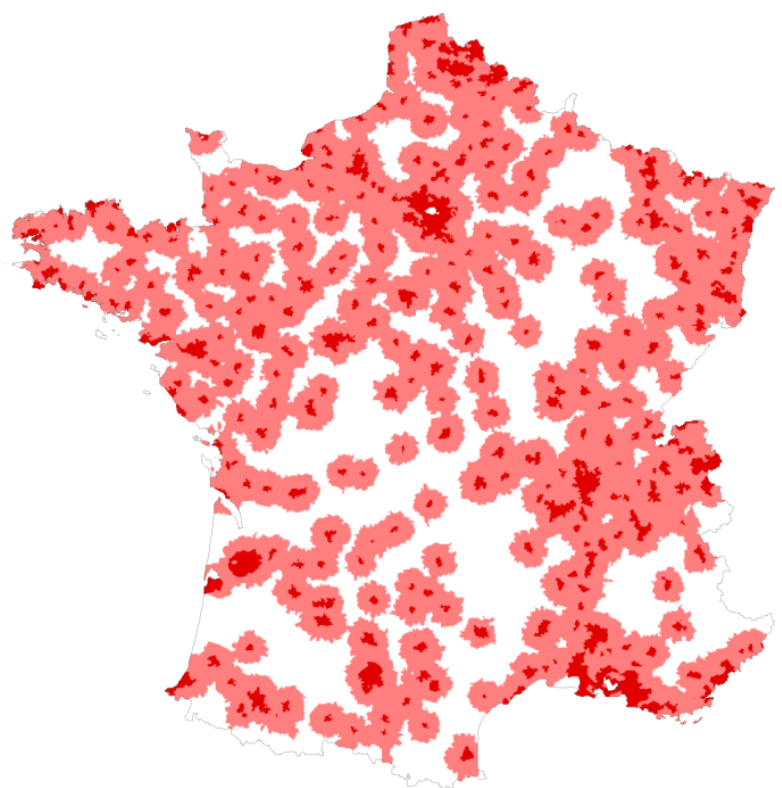

French urban municipalities studied $(2,895)$

French non-urban municipalities within $20 \mathrm{~km}$ distance from the studied municipalities $(23,142)$ 
Map 1. Contiguity matrix vs. distance based matrix in the refined model: An illustrative example with the "Communauté d'agglomération du Grand Dijon"

Map 1.1. $W^{C T G}$ : The case of Talant

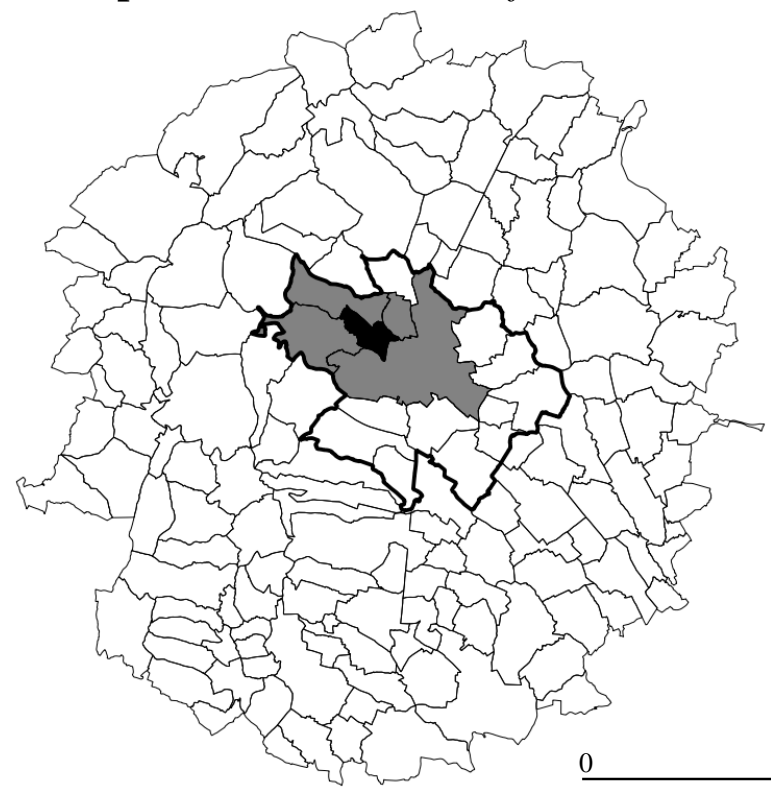

Map 1.2. $W^{C T G}$ : The case of Perrigny

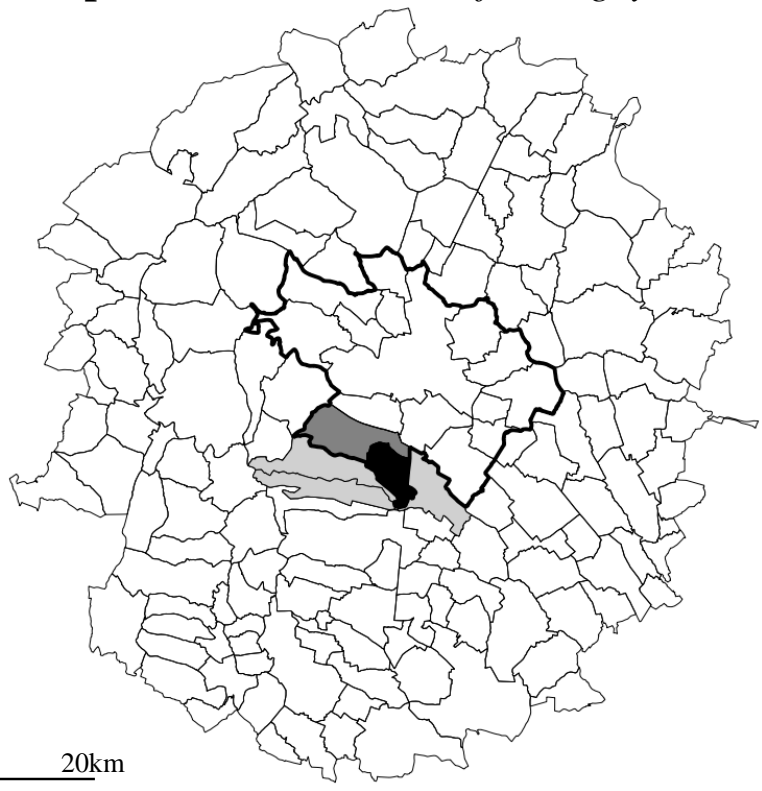

Neighbors within the EPCI

$W^{S A M E}$ with the contiguity matrix

Neighbors outside the EPCI

$W^{\text {OTHER }}$ with the contiguity matrix
Map 1.3. $W^{D I S T<20 k m}$ : The case of Talant

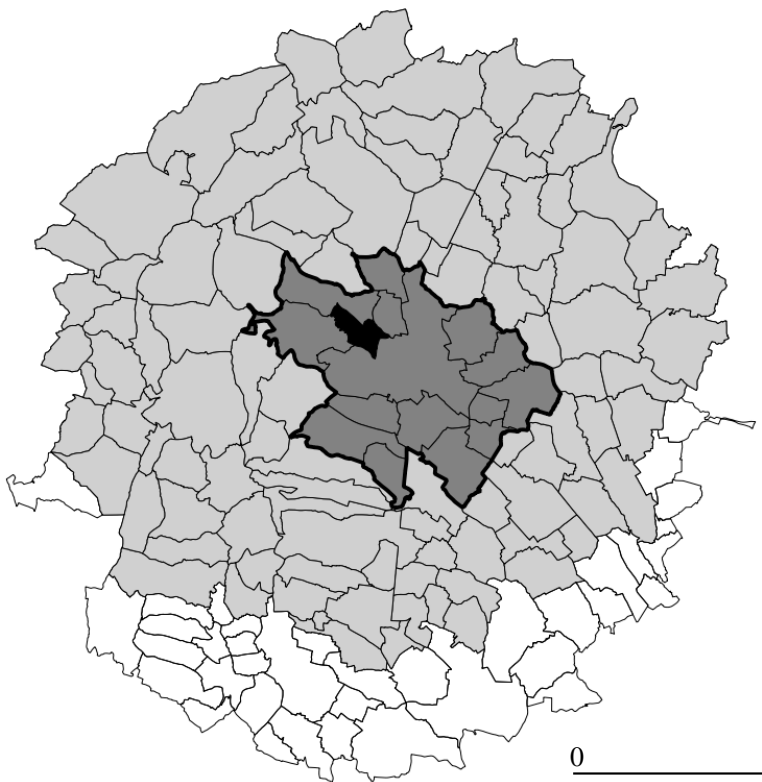

Map 1.4. $W^{D I S T<20 k m}$ : The case of Perrigny

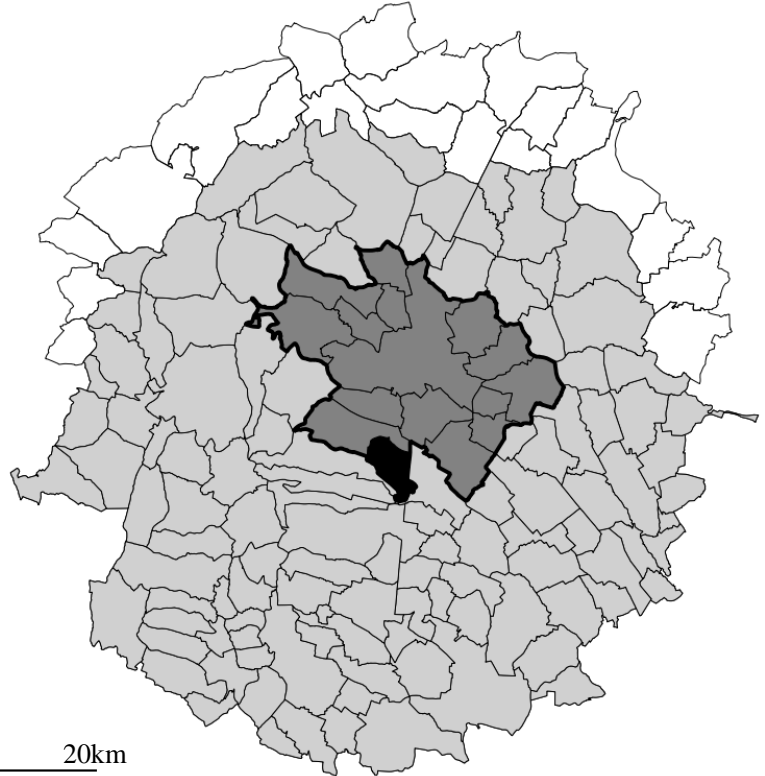

Municipalities' borders

The EPCI's borders
Neighbors within the EPCI

$W^{S A M E}$ with the distance based matrix

Neighbors outside the EPCI

$W^{\text {OTHER }}$ with the distance based matrix 
Table 2. Estimation results of the simple spatial model of municipal spending using a distance based weight matrix with a threshold at 20km, 1994-2003.

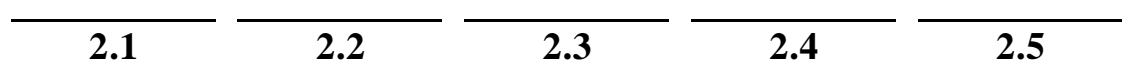

Methodology \& weight matrix

$2.1-\frac{2.3}{2.4}-\frac{2.5}{2.4}$

GMM-cluster GMM-cluster GMM-cluster GMM-cluster GMM-cluster

$\mathrm{W}^{\text {DIST }<20 k m} \quad \mathrm{~W}^{\text {DIST }<20 k m} \quad \mathrm{~W}^{\text {DIST<20km }} \quad \mathrm{W}^{\text {DIST<20km }} \quad \mathrm{W}^{\text {DIST }<20 k m}$

\section{Parame ter estimates (P-values)}

\begin{tabular}{|c|c|c|c|c|c|}
\hline \multirow[t]{2}{*}{$W Z_{j, t}$} & $0.744 * * *$ & $0.740 * * *$ & $0.775^{* *}$ & $0.744 * * *$ & $0.703 * *$ \\
\hline & $(0.002)$ & $(0.002)$ & $(0.023)$ & $(0.002)$ & $(0.024)$ \\
\hline \multirow[t]{2}{*}{ Coop $_{i, t}$} & - & -0.002 & 0.019 & - & - \\
\hline & - & $(0.715)$ & (0.899) & - & - \\
\hline \multirow[t]{2}{*}{$Z_{I, t}$} & - & - & - & 0.001 & -0.029 \\
\hline & - & - & - & $(0.927)$ & $(0.839)$ \\
\hline \multirow{2}{*}{ Density $_{i, t}$} & -0.037 & -0.036 & -0.038 & -0.037 & -0.037 \\
\hline & $(0.614)$ & $(0.616)$ & (0.604) & $(0.615)$ & $(0.609)$ \\
\hline \multirow[t]{2}{*}{ Pct_Young $_{i, t}$} & 0.315 & 0.318 & 0.291 & 0.315 & 0.304 \\
\hline & $(0.337)$ & $(0.333)$ & $(0.438)$ & $(0.337)$ & $(0.360)$ \\
\hline \multirow[t]{2}{*}{ Pct_Old $_{i, t}$} & 0.127 & 0.127 & 0.126 & 0.127 & 0.123 \\
\hline & $(0.652)$ & $(0.652)$ & $(0.652)$ & $(0.651)$ & $(0.664)$ \\
\hline \multirow[t]{2}{*}{ Mean_Income ${ }_{i, t}$} & $-0.051^{*}$ & $-0.051^{*}$ & $-0.052^{*}$ & $-0.051^{*}$ & $-0.050 *$ \\
\hline & $(0.061)$ & $(0.062)$ & $(0.064)$ & $(0.061)$ & $(0.070)$ \\
\hline \multirow[t]{2}{*}{ Tax_Capacity $_{i, t}$} & $0.122 * * *$ & $0.122 * * *$ & $0.122 * * *$ & $0.122 * * *$ & $0.123 * * *$ \\
\hline & $(0.000)$ & $(0.000)$ & $(0.000)$ & $(0.000)$ & $(0.000)$ \\
\hline \multirow[t]{2}{*}{ Grant $_{i, t}$} & 0.020 & 0.020 & 0.021 & 0.020 & 0.020 \\
\hline & $(0.633)$ & $(0.634)$ & $(0.629)$ & $(0.633)$ & $(0.637)$ \\
\hline Year_Fixed_Effects ${ }_{t}$ & yes*** & yes $* * *$ & yes**** & yes*** & yes*** \\
\hline
\end{tabular}

General statis tics

$\begin{array}{lccccc}\text { Number of clusters } & 2895 & 2895 & 2895 & 2895 & 2895 \\ \text { Number of observations } & 28950 & 28950 & 28950 & 28950 & 28950 \\ \text { dity of instruments } & & & & & \end{array}$

Validity of instruments

$\begin{array}{llllll}\text { Hansen J statistic }^{\#} & 2.304 & 2.310 & 2.260 & 2.306 & 2.274 \\ & (0.512) & (0.511) & (0.323) & (0.511) & (0.321)\end{array}$

$\underline{1^{\text {st }} \text { step R-squares }}$

$\begin{array}{lccccc}W Z_{j, t} & 0.4316 & 0.4322 & 0.4316 & 0.4317 & 0.4316 \\ \text { Coop }_{i, t} & - & - & 0.2217 & - & - \\ Z_{I, t} & - & - & - & - & 0.2831\end{array}$

$p$-values in parentheses $* p<0.10, * * p<0.05, * * * p<0.01$.

(2.1) to (2.5) instruments: spatial lag with the $W^{\text {DIST }<20 \mathrm{~km}}$ weight matrix of pct_young, pct_old, mean_income, grant.

${ }^{*}$ The Hansen J statistic follows a chi-squared distribution under the joint null hypothesis that the instruments are valid instruments, i.e. that they are uncorrelated with the error term and that the excluded instruments are correctly excluded from the estimated equation. Besides, this statistic is robust to within cluster correlation. In our results, we are always in the acceptance region, what allows us to conclude that our sets of instruments are always valid. 
Table 3. Estimation results of the refined spatial model of municipal spending using a distance based weight matrix with a threshold at 20km, 1994-2003.

$\overline{3.1} \longrightarrow \frac{3.3}{3.4} \overline{3.5}$

$\underline{\text { Methodology \& weight matrix }}$

Parame ter estimates (P-values)

$\begin{array}{ccccc}\text { GMM-cluster } & \text { GMM-cluster } & \text { GMM-cluster } & \text { GMM-cluster } & \text { GMM-cluster } \\ \mathrm{W}^{\mathrm{DIST}<20 \mathrm{~km}} & \mathrm{~W}^{\mathrm{DIST}<20 \mathrm{~km}} & \mathrm{~W}^{\mathrm{DIST}<20 \mathrm{~km}} & \mathrm{~W}^{\text {DIST<20km }} & \mathrm{W}^{\mathrm{DIST}<20 \mathrm{~km}}\end{array}$

\begin{tabular}{|c|c|c|c|c|c|}
\hline \multirow[t]{2}{*}{$W^{\text {SAME }} Z_{j, t}$} & $-0.006^{*}$ & $0.049 * *$ & 0.029 & -0.005 & 0.022 \\
\hline & $(0.058)$ & $(0.021)$ & $(0.183)$ & $(0.219)$ & $(0.266)$ \\
\hline \multirow[t]{2}{*}{$W^{\text {OTHER }} Z_{j, t}$} & $-0.224 * *$ & -0.147 & $-0.164^{*}$ & $-0.232 * *$ & $-0.360 * * *$ \\
\hline & $(0.013)$ & $(0.125)$ & $(0.086)$ & $(0.012)$ & $(0.006)$ \\
\hline \multirow[t]{2}{*}{ Coop $_{i, t}$} & - & $-0.122 * * *$ & -0.078 & - & - \\
\hline & - & $(0.010)$ & $(0.107)$ & - & - \\
\hline \multirow[t]{2}{*}{$Z_{I, t}$} & - & - & - & -0.006 & -0.148 \\
\hline & - & - & - & (0.648) & $(0.153)$ \\
\hline \multirow[t]{2}{*}{ Density $_{i, t}$} & 0.081 & 0.057 & 0.064 & 0.081 & 0.070 \\
\hline & $(0.263)$ & $(0.429)$ & $(0.374)$ & $(0.260)$ & $(0.343)$ \\
\hline \multirow[t]{2}{*}{ Pct_Young ${ }_{i, t}$} & 0.426 & 0.432 & 0.435 & 0.421 & 0.306 \\
\hline & $(0.205)$ & (0.194) & (0.193) & $(0.210)$ & $(0.378)$ \\
\hline \multirow[t]{2}{*}{ Pct_Old $_{i, t}$} & 0.380 & 0.364 & 0.353 & 0.378 & 0.338 \\
\hline & $(0.184)$ & $(0.200)$ & $(0.213)$ & $(0.186)$ & $(0.242)$ \\
\hline \multirow[t]{2}{*}{ Mean_Income ${ }_{i, t}$} & -0.041 & -0.040 & -0.040 & -0.041 & -0.036 \\
\hline & $(0.140)$ & $(0.154)$ & $(0.154)$ & (0.141) & $(0.209)$ \\
\hline \multirow[t]{2}{*}{ Tax_Capacity $_{i, t}$} & $0.126^{* * * *}$ & $0.125 * * *$ & $0.124 * * *$ & $0.127 * * *$ & $0.131 * * *$ \\
\hline & $(0.000)$ & $(0.000)$ & $(0.000)$ & $(0.000)$ & $(0.000)$ \\
\hline \multirow[t]{2}{*}{ Grant $_{i, t}$} & 0.015 & 0.014 & 0.016 & 0.015 & 0.0122 \\
\hline & $(0.737)$ & $(0.739)$ & $(0.717)$ & $(0.736)$ & $(0.783)$ \\
\hline Year_Fixed_Effects ${ }_{t}$ & yes*** & yes $* * *$ & yes*** & yes $* * *$ & yes*** \\
\hline
\end{tabular}

General statis tics

\begin{tabular}{|c|c|c|c|c|c|}
\hline Number of clusters & 2895 & 2895 & 2895 & 2895 & 2895 \\
\hline Number of observations & 28950 & 28950 & 28950 & 28950 & 28950 \\
\hline
\end{tabular}

Validity of instruments

$\begin{array}{llllll}\text { Hansen J statistic }^{\#} & 5.464 & 1.773 & 2.993 & 5.326 & 3.251 \\ & (0.362) & (0.621) & (0.559) & (0.377) & (0.517)\end{array}$

\section{$1^{\text {st }}$ step R-squares}

$\begin{array}{lccccc}W^{\text {SAME }} Z_{j, t} & 0.9752 & 0.9752 & 0.9752 & 0.9752 & 0.9752 \\ W^{\text {OTHER }} Z_{j, t} & 0.3854 & 0.3849 & 0.3854 & 0.3859 & 0.3854 \\ \text { Cоор }_{i, t} & - & - & 0.9988 & - & - \\ Z_{I, t} & - & - & - & - & 0.6496\end{array}$

$p$-values in parentheses $* p<0.10, * * p<0.05, * * * p<0.01$.

(3.1), (3.3), (3.4), (3.5) instruments: spatial lag with the $W^{\text {SAME }}$ weight matrix of pct_young, mean_income, tax_capacity, grant; spatial lag with the $W^{\text {OTHER }}$ weight matrix of density, pct_young, tax_capacity.

(3.2) instruments: spatial lag with the $W^{\text {SAME }}$ weight matrix of tax_capacity, grant; spatial lag with the $W^{\text {OTHER }}$ weight matrix of density, pct_young, tax_capacity.

${ }^{\text {\# } T h e ~ H a n s e n ~ J ~ s t a t i s t i c ~ f o l l o w s ~ a ~ c h i-s q u a r e d ~ d i s t r i b u t i o n ~ u n d e r ~ t h e ~ j o i n t ~ n u l l ~ h y p o t h e s i s ~ t h a t ~ t h e ~ i n s t r u m e n t s ~ a r e ~ v a l i d ~}$ instruments, i.e. that they are uncorrelated with the error term and that the excluded instruments are correctly excluded from the estimated equation. Besides, this statistic is robust to within cluster correlation. In our results, we are always in the acceptance region, what allows us to conclude that our sets of instruments are always valid. 
Appendix A1. Estimation results without spatial interactions, 1994-2003.

\begin{tabular}{|c|c|c|c|c|c|}
\hline & A1.1 & A1.2 & A1.3 & A1.4 & A1.5 \\
\hline Methodoloov \& weight matr & & & & & \\
\hline & $\begin{array}{c}\text { Cluster } \\
\mathrm{W}^{\mathrm{DIST}<20 \mathrm{~km}}\end{array}$ & $\begin{array}{c}\text { Cluster } \\
\mathrm{W}^{\mathrm{DIST}<20 \mathrm{~km}}\end{array}$ & $\begin{array}{c}\text { Cluster } \\
\mathrm{W}^{\mathrm{DIST}<20 \mathrm{~km}}\end{array}$ & $\begin{array}{c}\text { Cluster } \\
\mathrm{W}^{\mathrm{DIST}<20 \mathrm{~km}}\end{array}$ & $\begin{array}{c}\text { Cluster } \\
\mathrm{W}^{\mathrm{DIST}<20 \mathrm{~km}}\end{array}$ \\
\hline
\end{tabular}

Parameter estimates (P-values)

\begin{tabular}{|c|c|c|c|c|c|}
\hline \multirow[t]{2}{*}{ Coop $_{i, t}$} & - & -0.008 & $-0.300 * *$ & - & - \\
\hline & - & $(0.174)$ & $(0.023)$ & - & - \\
\hline \multirow[t]{2}{*}{$Z_{I, t}$} & - & - & - & -0.005 & $-0.466 * * *$ \\
\hline & - & - & - & $(0.600)$ & $(0.008)$ \\
\hline \multirow{2}{*}{ Density $_{i, t}$} & 0.056 & 0.055 & 0.023 & 0.055 & -0.047 \\
\hline & $(0.428)$ & $(0.435)$ & $(0.773)$ & $(0.438)$ & $(0.589)$ \\
\hline \multirow[t]{2}{*}{ Pct_Young ${ }_{i, t}$} & 0.363 & 0.370 & $0.662^{*}$ & 0.361 & 0.215 \\
\hline & $(0.280)$ & $(0.270)$ & $(0.087)$ & $(0.282)$ & $(0.567)$ \\
\hline \multirow[t]{2}{*}{ Pct_Old $_{i, t}$} & 0.353 & 0.351 & 0.259 & 0.350 & 0.038 \\
\hline & $(0.214)$ & $(0.218)$ & $(0.423)$ & $(0.219)$ & $(0.911)$ \\
\hline \multirow[t]{2}{*}{ Mean_Income $_{i, t}$} & -0.044 & -0.044 & -0.035 & -0.044 & -0.035 \\
\hline & $(0.111)$ & $(0.113)$ & $(0.225)$ & $(0.112)$ & $(0.230)$ \\
\hline \multirow[t]{2}{*}{ Tax_Capacity $_{i, t}$} & $0.128 * * *$ & $0.128 * * *$ & $0.134 * * *$ & $0.128 * * *$ & $0.145^{* * *}$ \\
\hline & $(0.000)$ & $(0.000)$ & $(0.000)$ & $(0.000)$ & $(0.000)$ \\
\hline \multirow[t]{2}{*}{ Grant $_{i, t}$} & 0.019 & 0.019 & 0.016 & 0.019 & 0.018 \\
\hline & $(0.656)$ & $(0.656)$ & $(0.746)$ & $(0.656)$ & $(0.722)$ \\
\hline Year_Fixed_Effects ${ }_{t}$ & yes $* * *$ & yes**** & yes**** & yes*** & yes**** \\
\hline
\end{tabular}

General statistics

$\begin{array}{lccccc}\text { Number of clusters } & 2895 & 2895 & 2895 & 2895 & 2895 \\ \text { Number of observations } & 28950 & 28950 & 28950 & 28950 & 28950\end{array}$

Validity of ins truments

\begin{tabular}{|c|c|c|c|c|c|}
\hline Hansen J statistic ${ }^{\#}$ & - & - & 2.964 & - & 0.997 \\
\hline & - & - & $(0.227)$ & - & $(0.607)$ \\
\hline \multicolumn{6}{|l|}{$1^{\text {st }}$ step R-s quares } \\
\hline $\operatorname{Coop}_{i, t}$ & - & - & 0.2212 & - & - \\
\hline$Z_{I, t}$ & - & - & - & - & 0.2805 \\
\hline
\end{tabular}

p-values in parentheses $* p<0.10, * * p<0.05, * * * p<0.01$.

(A1.3), (A1.5) instruments: spatial lag with the $W^{\text {DIST<20km }}$ weight matrix of pct_old, tax_capacity, grant.

${ }^{\#}$ The Hansen J statistic follows a chi-squared distribution under the joint null hypothesis that the instruments are valid instruments, i.e. that they are uncorrelated with the error term and that the excluded instruments are correctly excluded from the estimated equation. Besides, this statistic is robust to within cluster correlation. In our results, we are always in the acceptance region, what allows us to conclude that our sets of instruments are always valid. 
Appendix A2. Estimation results of the simple spatial model of municipal spending using a distance based weight matrix with a threshold at 15km, 1994-2003.

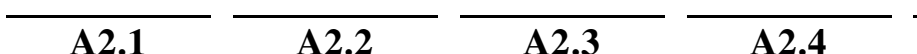

A2.5

Methodology \& we ight matrix

\begin{tabular}{|c|c|c|c|c|c|}
\hline \multirow{2}{*}{$W Z_{j, t}$} & $0640 * * *$ & $0637 * * *$ & $0737 * *$ & $0637 * * *$ & $0.562 *$ \\
\hline & $(0.007)$ & $(0.008)$ & $(0.021)$ & $(0.007)$ & $(0.089)$ \\
\hline \multirow[t]{2}{*}{ Coop $_{i, t}$} & - & -0.003 & 0.063 & - & - \\
\hline & - & $(0.600)$ & $(0.650)$ & - & - \\
\hline \multirow[t]{2}{*}{$Z_{I, t}$} & - & - & - & -0.002 & -0.062 \\
\hline & - & - & - & $(0.803)$ & $(0.729)$ \\
\hline \multirow[t]{2}{*}{ Density $_{i, t}$} & -0.027 & -0.027 & -0.032 & -0.027 & -0.030 \\
\hline & $(0.707)$ & $(0.709)$ & $(0.667)$ & $(0.707)$ & $(0.688)$ \\
\hline \multirow{2}{*}{ Pct_Young $_{i, t}$} & 0.350 & 0.355 & 0.274 & 0.349 & 0.325 \\
\hline & $(0.285)$ & $(0.279)$ & $(0.460)$ & $(0.287)$ & $(0.334)$ \\
\hline \multirow[t]{2}{*}{ Pct_Old ${ }_{i, t}$} & 0.158 & 0.157 & 0.160 & 0.157 & 0.144 \\
\hline & $(0.574)$ & $(0.576)$ & $(0.566)$ & $(0.575)$ & $(0.614)$ \\
\hline \multirow[t]{2}{*}{ Mean_Income ${ }_{i, t}$} & $-0.048^{*}$ & $-0.048^{*}$ & $-0.051^{*}$ & $-0.048^{*}$ & $-0.046^{*}$ \\
\hline & $(0.077)$ & $(0.078)$ & $(0.069)$ & $(0.078)$ & $(0.095)$ \\
\hline \multirow[t]{2}{*}{ Tax_Capacity $_{i, t}$} & $0.122 * * *$ & $0.122 * * *$ & $0.121 * * *$ & $0.122 * * *$ & $0.125^{* * *}$ \\
\hline & $(0.000)$ & $(0.000)$ & $(0.000)$ & $(0.000)$ & $(0.000)$ \\
\hline \multirow[t]{2}{*}{ Grant $_{i, t}$} & 0.024 & 0.024 & 0.026 & 0.024 & 0.023 \\
\hline & $(0.572)$ & $(0.573)$ & $(0.543)$ & $(0.572)$ & $(0.589)$ \\
\hline $\begin{array}{l}\text { Year_Fixed_Effects }{ }_{t} \\
\text { General statistics }\end{array}$ & yes*** & yes**** & yes**** & yes**** & yes*** \\
\hline Number of clusters & 2895 & 2895 & 2895 & 2895 & 2895 \\
\hline Number of observations & 28950 & 28950 & 28950 & 28950 & 28950 \\
\hline \multicolumn{6}{|l|}{ Validity of ins truments } \\
\hline \multirow[t]{2}{*}{ Hansen J statistic } & 2.140 & 2.165 & 1.854 & 2.132 & 2.054 \\
\hline & $(0.544)$ & $(0.539)$ & $(0.396)$ & $(0.545)$ & $(0.358)$ \\
\hline \multicolumn{6}{|l|}{$1^{\text {st }}$ step R-squares } \\
\hline$W Z_{j, t}$ & 0.3720 & 0.3726 & 0.3720 & 0.3720 & 0.3720 \\
\hline Coop $_{i, t}$ & - & - & 0.2216 & - & - \\
\hline$Z_{I, t}$ & - & - & - & - & 0.2815 \\
\hline
\end{tabular}

GMM-cluster GMM-cluster GMM-cluster GMM-cluster GMM-cluster $\mathrm{W}^{\text {DIST }<15 \mathrm{~km}} \quad \mathrm{~W}^{\text {DIST }<15 \mathrm{~km}} \quad \mathrm{~W}^{\text {DIST }<15 \mathrm{~km}} \quad \mathrm{~W}^{\text {DIST }<15 \mathrm{~km}} \quad \mathrm{~W}^{\text {DIST }<15 \mathrm{~km}}$

\section{Parameter estimates (P-values)}

$p$-values in parentheses $* p<0.10, * * p<0.05, * * * p<0.01$.

(A2.1) to (A2.5) instruments: spatial lag with the $W^{\text {DIST<15km }}$ weight matrix of pct_young, pct_old, mean_income, grant.

${ }^{*}$ The Hansen J statistic follows a chi-squared distribution under the joint null hypothesis that the instruments are valid instruments, i.e. that they are uncorrelated with the error term and that the excluded instruments are correctly excluded from the estimated equation. Besides, this statistic is robust to within cluster correlation. In our results, we are always in the acceptance region, what allows us to conclude that our sets of instruments are always valid. 
Appendix A3. Estimation results of the simple spatial model of municipal spending using a contiguity matrix, 1994-2003.

$\overline{\mathrm{A3.1}} \frac{\mathrm{A3.2}}{\mathrm{A3.3}} \frac{\mathrm{A3.4}}{\mathrm{A3.5}}$

$\underline{\text { Methodology \& we ight matrix }}$

GMM-cluster GMM-cluster GMM-cluster GMM-cluster GMM-cluster

$\mathrm{W}^{\mathrm{CTG}} \quad \mathrm{W}^{\mathrm{CTG}} \quad \mathrm{W}^{\mathrm{CTG}} \quad \mathrm{W}^{\mathrm{CTG}} \quad \mathrm{W}^{\mathrm{CTG}}$

Parameter estimates (P-values)

$\begin{array}{lccccc}W Z_{j, t} & 0.097 & 0.095 & -0.788 & 0.093 & -0.389 \\ & (0.739) & (0.746) & (0.342) & (0.751) & (0.474) \\ \text { Coop }_{i, t} & - & -0.008 & 0.348 & - & - \\ & - & (0.220) & (0.287) & - & - \\ Z_{I, t} & - & - & - & -0.005 & -0.545 \\ & - & - & - & (0.578) & (0.288) \\ \text { Density }_{i, t} & 0.048 & 0.047 & 0.152 & 0.047 & -0.027 \\ & (0.519) & (0.524) & (0.228) & (0.525) & (0.820) \\ \text { Pct_Young }_{i, t} & 0.378 & 0.386 & -0.004 & 0.375 & 0.158 \\ & (0.256) & (0.246) & (0.994) & (0.259) & (0.713) \\ \text { Pct_Old }_{i, t} & 0.335 & 0.332 & 0.645 & 0.333 & 0.089 \\ & (0.238) & (0.243) & (0.140) & (0.242) & (0.824) \\ \text { Mean_Income }_{i, t} & -0.047 * & -0.046^{*} & -0.052 & -0.047 * & -0.030 \\ & (0.091) & (0.093) & (0.164) & (0.092) & (0.357) \\ \text { Tax_Capacity }_{i, t} & 0.126^{* * *} & 0.126^{* * *} & 0.118^{* * *} & 0.126^{* * *} & 0.145^{* * * *} \\ & (0.000) & (0.000) & (0.000) & (0.000) & (0.000) \\ \text { Grant }_{i, t} & 0.015 & 0.015 & -0.005 & 0.015 & 0.005 \\ & (0.721) & (0.724) & (0.929) & (0.723) & (0.920) \\ \text { Year_Fixed_Effects }_{t} & \text { yes*** } & \text { yes**** } & \text { yes*** } & \text { yes*** } & \text { yes*** }\end{array}$

General statistics

\begin{tabular}{|c|c|c|c|c|c|}
\hline Number of clusters & 2895 & 2895 & 2895 & 2895 & 2895 \\
\hline $\begin{array}{l}\text { Number of observations } \\
\text { dity of instruments }\end{array}$ & 28950 & 28950 & 28950 & 28950 & 28950 \\
\hline \multirow[t]{2}{*}{ Hansen J statistic \# } & 4.245 & 4.289 & 0.799 & 4.218 & 2.289 \\
\hline & $(0.236)$ & $(0.232)$ & (0.371) & $(0.239)$ & $(0.318)$ \\
\hline
\end{tabular}

$\underline{1^{\text {st }} \text { step R-squares }}$

$\begin{array}{lccccc}W Z_{j, t} & 0.1816 & 0.1819 & 0.1798 & 0.1816 & 0.1816 \\ \text { Coop }_{i, t} & - & - & 0.2193 & - & - \\ Z_{I, t} & - & - & - & - & 0.2784\end{array}$

$p$-values in parentheses $* p<0.10, * * p<0.05, * * * p<0.01$.

(A3.1), (A3.2), (A3.4), (A3.5) instruments: spatial lag with the $W^{C T G}$ weight matrix of pct_young, pct_old, mean_income, grant.

(A3.3) instruments: spatial lag with the $W^{C T G}$ weight matrix of pct_young, mean_income, grant.

${ }^{*}$ The Hansen J statistic follows a chi-squared distribution under the joint null hypothesis that the instruments are valid instruments, i.e. that they are uncorrelated with the error term and that the excluded instruments are correctly excluded from the estimated equation. Besides, this statistic is robust to within cluster correlation. In our results, we are always in the acceptance region, what allows us to conclude that our sets of instruments are always valid. 